\title{
Pencegahan Kekerasan Terhadap Anak Usia Dini di TK IT Bintang Kecil Kota Semarang
}

\author{
Nur Intan Rochmawati ${ }^{1}$, \\ Program Studi S1 PGPAUD Fakultas Ilmu Pendidikan dan Teknologi Informasi Universitas \\ Ngudi Waluyo \\ Adhi Budi Susilo \\ Program Studi S1 Hukum Fakutas Hukum dan Humaniora Univeritas Ngudi Waluyo
}

\begin{abstract}
Abstrak:Undang-Undang 35 tahun 2014 Tentang Perlindungan anak pada Pasal 1 ayat (1) menyebutkan Anak adalah seorang yang belum berusia 18 (delapan belas) tahun, termasuk anak yang masih dalam kandungan, adalah sebagai manusia seutuhnya anak memiliki harkat dan martabat,oleh karena itu anak memilki hak asasi yang diakui. Masa usia dini adalah masa peka dimana anak memiliki kemampuan penyerapan informasi yang luar biasa, serta rasa ingin tahu yang begitu tinggi tentang berbagai hal,. Pada usia ini anak membutuhkan penanganan dan respon yang tepat dari lingkungan terdekatnya.Undang-undang Nomor 20 Tahun 2003 tentang Sistem Pendidikan Nasional Pasal 1 angka 14 menyatakan bahwa Pendidikan Anak Usia Dini (PAUD) adalah suatau upaya pembinaan yang ditunjukkan kepada anak sejak lahir sampai enam tahun yang dilakukan melalui pemberian rangsangan pendidikan untuk membantu pertumbuhan dan perkembangan jasmani dan rohani agar anak memiliki kesiapan dalam memasuki pendidikan lanjut Dewasa ini terdapat berbagai fenomena perilaku negatif pada anak dalam kehidupan sehari hari. Jika kita lihat sekarang ini baik melalui surat kabar,televisi, radio atau kejadian disekiling kita, kekerasan terhadap anak makin marak terjadi, bahkan pelakunya berasal dari keluarganya sendiri. Hal ini menyebabkan anak-anak tersebut menjadi terlantar dan terisolasi dari kehidupan sosialnya. Sedangkan Menurut Undang-undang Perlindungan Anak Nomor 35 Tahun 2014 perlindungan anak adalah segala kegiatan untuk menjamin dan melindungi anak dan hakhaknya agar tetap hidup, tumbuh, berkembang, dan berpartisipasi secara optimal sesuai dengan harkat dan martabat kemanusiaan, serta mendapat perlindungan dari kekerasan dan diskriminasi

Obyek dalam penelitian ini sesuai dengan judul Pencegahan Kekerasan Terhadap Anak Usia Dini di TK IT Bintang Kecil Kota Semarang ini adalah anak usia dini yang mengikuti pendidikan di TK IT Bintang Kecil Kota Semarang dilakukan dengan bentuk mengenali dan mencegah kejadian kekerasan pada anak. Selanjutnya sebagai pengetahuan masyarakat dan pemerintah agar mengetahui pentingnya Perlindungan Anak khususnya sebagai usaha preventif agar angka kekerasan tidak semakin bertambah.
\end{abstract}

Kata Kunci : Pencegahan, Kekerasaan, Anak Usia Dini 


\section{PENDAHULUAN}

\section{A. Latar Belakang}

$$
\text { Undang-undang Republik }
$$

Indonesia Nomor 35 Tahun 2014 tentang perubahan Undang-Undang Nomor 23 tahun 2002 tentang Perlindungan Anak pada Pasal 1 ayat (1) menyebutkan bahwa anak adalah seseorang yang belum berusia 18 (delapan belas) tahun, termasuk anak yang masih dalam kandungan.dapat diartikan melekat harkat dan martabat sebagai manusia seutuhnya. Undangundang Nomor 20 Tahun 2003 tentang Sistem Pendidikan Nasional Pasal 1 angka 14 menyatakan bahwa Pendidikan Anak Usia Dini (PAUD) adalah suatau upaya pembinaan yang ditunjukkan kepada anak sejak lahir sampai enam tahun yang dilakukan melalui pemberian rangsangan pendidikan untuk membantu pertumbuhan dan perkembangan jasmani dan rohani agar anak memiliki kesiapan dalam memasuki pendidikan lanjut (Kementerian Pendidikan dan Kebudayaan. Dektorat Jendral Pendidikan Anak Usia Dini, Non Formal, dan Informal, 2014;1).

$$
\text { Penyebab terjadinya adanya }
$$
tindak kekerasan pada anak sangat bervariasi jenisnya salah satu bentuk kekerasan dalam rumah tangga adalah kekerasan yang dilakukan oleh orang tua, keluarga dan orang-orang disekitarnya kepada anaknya.ini diperkuat dengan Undang-Undang tentang Hak asasi Manusia Pasal 53 ayat (1) yang menyebutkan Setiap anak sejak dalam kandungan berhak untuk hidup, mempertahankan hidup dan meningkatkan kehidupan. Perkembangan kasus yang terjadi dewasa ini ternyata kekerasan pada anak terjadi dimana saja, keluarga yang seharusnya memberikan peran kenyamanan, perlindungan, bisa juga menjadi tempat terjadinya kekerasan pada anak. Meskipun tidak semua kekerasan ada pada tiap keluarga tetapi, jika ini pernah dialami anak tentu juga akan mempengaruhi perkembangan tahap berikutnya

$$
\text { Pada umumnya orang tua }
$$
menganggap kekerasan kepada anak merupakan urusan "dapur" satu keluarga dan bagian dari mendisiplinkan anak . Masih banyaknya orang tua yang beranggapan bahwa anaknya adalah hak milik dan tanggung jawab orang 
tua maka berhak melakukan apa saja, ternasuk memberikan hukumanhukuman yang dirasa pantas dilakukan oleh orang tuanya seperti contoh dipukul, dimarahi, dicubit, dijewer hingga disiksa Bagaimanapun juga anak usia dini belum bisa terlepas ketergantungannya terhadap orang dewasa di sekitar. Berdasarkan hal tersebut, sangatlah penting untuk merancang sebuah konsep pendidikan anak usia dini yang pengelolaannya mengacu pada prinsip 3P (Provisi, Proteksi, dan Partisipasi) dalam proses pembelajarannya.

Kekerasan pada anak atau lebih dikenal dengan istilah child abuse, disebut juga child maltreatment, menggambarkan perbuatan disengaja yang menimbulkan kerugian atau bahaya terhadap anak-anak secara fisik maupun emosional, Lawson, seorang psikiater anak mengklasifikasikan kekerasan pada anak menjadi empat bentuk, yaitu: emotional abuse, verbal abuse, physical abuse, dan sexual abuse (Huraerah, 2006).

Anak adalah tunas, potensi dan generasi penerus cita-cita bangsa, memiliki peran strategis yang menjamin kelangsungan eksistensi bangsa dan negara pada masa depan.
Agar anak mampu memikul tanggung jawab tersebut, maka ia perlu mendapat kesempatan yang seluasluasnya untuk tumbuh dan berkembang secara optimal, baik fisik, mental maupun sosial dan berakhlak mulia. Mereka perlu mendapatkan hak-haknya, perlu dilindungi dan disejahterakan. Segala bentuk tindakan kekerasan, penelantaran, diskriminasi dan perlakuan salah lainnya terhadap anak perlu dicegah dan diatasi. Menjadi tunas bangsa dan generasi yang unggul membutuhkan media yang sangat kondusif penuh dengan kenyamanan dan kasih sayang. Jika anak usia dini berkembang dengan lingkungan dan suasana yang kondusif perkembangan dan pertumbuhan akan berkembang melejit, begitu sebaliknya jika anak dalam proses pertumbuhan dan perkembangannya mengalami kekerasan sampai terjadi trauma maka perkembangannya akan terhambat dan megalami masa sulit seperti sulit diarahkan, sulit dikendalikan dan susah mengikuti aturan yang ada. Sebagai orang dewasa disekitar anak sangat diperlukan pemahaman terkait dengan stimulasi kebutuhan perkembangan dan perkembangan anak. 
Sekolah

memberikan

pelayanan kepada peserta didik dengan fasilitas yang ada di sekolah sesuai dengan aturan yang telah dibuat mengacu pada aturan Pendidikan yang telah diatur oleh Kementrian Pendidikan dan Kebudayaan sesuai dengan jenjang pendidikan yang dijabarkan dalam kurikulum. Sebagai Lembaga PAUD, TK IT Bintang Kecil menerapkan pembelajaran dengan menitik beratkan pada karakter anak yang berdasarkan pada aturan agama Islam. Selain itu memahami kondisi lingkungan sekitar sekolah untuk menguatkan program sekolah dengan memperhatikan latar belakang dan kondisi ekonomi, sosial, tingkat Pendidikan orang tua. Sebagaimana dengan program yang dikembangkan oleh Lembaga ini yaitu mendukung PAUD holistic Integratif yang menitik beratkan kepada Pendidikan, kesehatan anak meliputi gizi dan pemeriksaan kesehatan, serta memperhatikan pengasuhan dan pendampingan. Upaya yang telah dilakukan sekolah untuk mencapai program yang ada salah satunya dengan kegiatan parenting yang dilakukan dalam upaya menjalin dan membangun komunikasi yang baik dalam rangka mendidik anak usia dini.

\section{B. RUMUSAN MASALAH}

Berdasarkan pemaparan latar belakang masalah diatas, maka pokok masalah sebagai berikut : bagaimana pencegahan kekerasan pada anak usia diani dalam Undang-Undang 35 Tahun 204 tentang perlindungan anak?

\section{METODE PENELITIAN}

Penelitian ini merupakan penelitian yuridis analisis terkait pencegahan kekerasan terhadap anak oleh orang tua maupun penjelasan mengenai UU No.35 Tahun 2014 tentang Kekerasan anak

\section{PEMBAHASAN}

\section{DEFINISI DAN BENTUK} KEKERASAN TERHADAP ANAK

Tindak kekerasan terhadap anak saat ini umumnya masih dianggap urusan keluarga atau urusan rumah tangga yang bersangkutan sehingga orang luar tidak boleh atau tidak mau ikut campur. Orang tua tidak menyadari bahwa kekerasan yang dilakukan terhadap anaknya sendiri merupakan tindak kriminal dan bisa diajukan ke jalur hukum. Mindset orang tua yang menganggap bahwa anak kandung adalah miliknya dan haknya, sehingga bebas melakukan apapun terhadap anaknya sendiri. Memukul dengan 
maksud memberikan pembelajaran kepada anak. Mewujudkan kasih sayang kepada anak dengan marah, memaki adalah menyakiti perasaan dan fisik anak. Anak tidak memahami bahwa itu adalah wujud orang tua menyayanginya, akan tetapi yang tersimpan di memori jangka pandang anak adalah sakit secara fisik dan batin. Dampak lain yang ditimbulkan saat anak mengalami kekerasn munculnya perilaku yang sama yang dilakukan anak kepada orang lain/ teman sebayanya.

\section{Berdasarkan}

beberapa

pengertian di atas dapat disimpulkan pengertian kekerasan terhadap anak adalah perilaku salah baik dari orangtua, pengasuh dan lingkungan dalam bentuk perlakuan kekerasan fisik, psikis maupun mental yang termasuk didalamnya adalah penganiayaan, penelantaran dan ekspoitasi, mengancam dan lain-lain terhadap anak. Tindak kekerasan yang terjadi pada anak dapat dikelompokkan ke dalam bentuk tindak kekerasan berdasarkan dampak yang dialami oleh anak. Bentuk tindak kekerasan tersebut sebagai berikut :

1. Tindak kekerasan fisik, yaitu tindak kekerasan yang diarahkan secara fisik kepada anak, sehingga anak merasa tidak nyaman dengan tindakan tersebut.

2. Tindak kekerasan psikis, yaitu tindak kekerasan yang diarahkan pada psikis anak yang mengakibatkan terganggunya emosional anak sehingga dapat mempengaruhi tumbuh kembangnya.

3. Tindak kekerasan seksual, yaitu tindak kekerasan yang dialami oleh anak yang diarahkan pada alat reproduksinya, sehingga mengakibatkan terganggunya tumbuh kembang anak secara fisik, psikis maupun sosial anak.

4. Penelantaran, yaitu tindak kekerasan yang dialami anak baik disengaja atau tidak sengaja, yang mengakibatkan tidak terpenuhinya kebutuhan dasar anak untuk tumbuh kembang.

\section{PELAKU TINDAK KEKERASAN TERHADAP ANAK}

Pelaku tindak kekerasan anak seringkali melibatkan orang terdekat anak,. Pelaku tindak kekerasan terhadap anak dapat dibagi menjadi dua kategori. 
1. Keluarga yang dimaksud keluarga sebagai pelaku tindak kekerasan adalah orang yang mempunyai hubungan keluarga dengan anak karena hubungan darah, perkawinan, persusuan, pengasuhan, dan perwalian,

2. Di luar keluarga yaitu orang-orang atau pelaku di luar kategori keluarga, misalnya, tetangga, petugas sekolah (guru, kepala sekolah, guru BP, penjaga sekolah, dan lain sebagainya), dan orang yang tidak dikenal anak.

PENCEGAHAN

TINDAK KEKERASAN TERHADAP ANAK

Pencegahan tindak kekerasan terhadap anak merupakan upaya yang harus dilakukan oleh semua pihak, baik negara, pemerintah, masyarakat, keluarga, maupun anak itu sendiri. Undang-Undang Nomor 35 Tahun 2014 tentang Penghapusan Kekerasan Dalam Rumah Tangga Pasal 15 menyatakan bahwa

"Setiap orang yang mendengar, melihat, atau mengetahui terjadinya tindak kekerasan dalam rumah tangga wajib melakukan upaya-upaya sesuai dengan batas kemampuannya untuk: a) mencegah berlangsungnya tindak pidana; b) memberikan perlindungan kepada korban; c) memberikan pertolongan darurat; dan c) membantu proses pengajuan permohonan penetapan perlindungan.
Upaya pencegahan tindak kekerasan terhadap anak dapat dilakukan dengan cara sebagai berikut: di lingkungan keluarga 1)Peningkatan keimanan dan ketakwaan terhadap Tuhan Yang Maha Esa. 2) Peningkatan pemahaman tentang hak asasi manusia, hak-hak anak, dan kesetaraan gender. 3) Peningkatan kesadaran hukum dan dampak tindak kekerasan terhadap anak. 4) Pengintegrasian program pencegahan tindak kekerasan terhadap anak dalam program pemberdayaan keluarga.

Penerapan pola pengasuhan anak yang bebas dari tindak kekerasan, dan penguatan pendidikan anti tindak kekerasan sejak dini di tingkat keluarga. Di lingkungan Masyarakat 1. Peningkatan pemahaman tentang hak asasi manusia, hak-hak anak, dan kesetaraan gender, 2. Peningkatan kesadaran masyarakat tentang hukum dan dampak tindak kekerasan terhadap anak, 3. Pengintegrasian program pencegahan tindak kekerasan terhadap anak dalam program pemberdayaan masyarakat, 4. Penguatan peran komunitas peduli anak melalui pelatihan pola pengasuhan anak, 5 . Mendorong upaya penegakan ketentuan Peraturan Perundang- 
undangan Republik Indonesia untuk mencegah tindak kekerasan terhadap anak. Pada pelaksanaannya, pencegahan tindak kekerasan terhadap anak dalam keluarga dapat dilakukan dengan mengintegrasikannya dalam pola pengasuhan yang bebas dari tindak kekerasan. Sedangkan peran serta masyarakat dalam pencegahan tindak kekerasan terhadap anak bisa dilakukan melalui pola penguatan komunitas peduli anak.

\section{SIMPULAN}

Pencegahan kekerasan anak memerlukan sinergi antara pihakpihak yang terkait dalam ruang lingkup informal, formal dan non formal seperti yang sudah diuraikan di atas maka dapat disimpulkan yaitu:

1. Kekerasan pada anak bisa terjadi di manapun anak berada, stop melakukan kekerasan terhadap anak. Mengasuh dan mendidik dengan mengedepankan hak-hak anak sesuai dengan tahapan dan kebutuhan anak menjadikan perkembangan anak berkembang sesuai harapan.

2. Diperlukan sinergi yang kuat antara keluarga, sekolah/Lembaga serta masyarakat untuk berperan aktif dalam menciptakan lingkungan dan suasana ramah anak sehubungan dengan tujuan pencegahan kekerasan pada anak. Melalui lingkungan yang kondusif dan ramah anak pertumbuhan dan perkembangan anak akan lebih optimal sehingga akan meningkatkan kualitas tunas bangsa sebagai penerus negara.

\section{SARAN}

Berdasarkan konsep yang sudah disampaikan tentang Pendidikan ramah anak sebagai upaya pencegahan kekerasan pada anak maka direkomendasikan beberapa hal yaitu:

1. Penerapan Pendidikan ramah anak hendaknya terus dikembangkan dengan inovasi-inovasi pembelajaran karena zaman selalu berkembang dan peserta didikpun harus mengikuti perkembangan yang terjadi.

2. Pengelolaan PAUD yang peduli dengan berbagai masalah yang dihadapi peserta didik terkait dengan optimalisasi tumbuh kembang anak lebih dapat diintensifkan lagi program pengembangannya.

3. Dalam upaya mendapatkan hasil yang maksimal, konsep yang ditulis tentang Pendidikan PAUD 
ramah anak sebagai upaya pencegahan pada anak dapat dijadikan rujukan dalam penelitian anak usia dini sehingga implikasi dilapangan scara langsung dapat dilihat dilapangan

\section{REFERENSI}

Kementrian Pendidikan Dan Kebudayaan Direktorat Jendral Pendidikan Anak Usia Dini, Non Formal, dan Informal. Pengembangan Perencanaan Pembelajaran Program PAUD 2014

Kementrian Pendidikan Dan

Kebudayaan Direktorat Jendral Pendidikan Anak Usia Dini, Non Formal, dan Informal. Program Pemberdayaan Orang Tua Pada PAUD 2014

Komisi Perlindungan Anak Indonesia,http://www.kpai.go.(

Di akses 16 November 2015).http://www.setneg.go.id

Luluk, Elyana. Pengelolaan PAUD Ramah Anak Berbasis Masyarakat Melalui Pendekatan Wikipedia Bahasa Indonesia, Ensiklopedia bebas,.(di akses 16 November 2015)
Metakognisi. Majalah Ilmiah Pawiyatan Vol:XXII,No.1, Mei 2015

Senowarsito, Arisul Ulmuddin. Implementasi Pendidikan Ramah Anak Dalam Konteks Membangun Karakter Siswa Di Sekolah Dasar Negeri Di Kota Semarang.hhtt//www...(diakses 15 November 2015)

Seputarpendidikan003.blogspot.com/ .../konsep-dasar-...Dec 6, 2013(diakses $16 \quad$ November 2015)

Salinan Undang-undang Nomor 20 Tahun 2003 tentang Sistem Pendidikan Nasional Pasal 1 angka 14

Tomindflys.blogspot.com/.../sekolahramah-anak.htm/Feb 14, 2010 , diakses 16 November 2015)

UU PA No. 23 Tahun 2003 tentang perlindungan Anak

www.psychologymania.com/.../penger tian -kekerasan-t.(di akses 16 November 2015)

www.slideshare.net/.../makalah konsep-dasar-paud-1Jan 24,2015(di akses 16 November 2015) 